\title{
SPATIAL DISTRIBUTION OF CANINE VISCERAL LEISHMANIASIS IN ILHA SOLTEIRA, SÃO PAULO, BRAZIL
}

\section{SILVANA DE C. PAULAN ${ }^{1}$, HÉLIO R. SILVA ${ }^{2}$, ELIZETE A. C. DE FREITAS LIMA ${ }^{3}$, EDÍLSON F. FLORES ${ }^{4}$, VILMA M. TACHIBANA ${ }^{5}$, CLÁUDIA Z. KANDA ${ }^{6}$, ANTONIO C. F. DE NORONHA JUNIOR ${ }^{7}$, PAULO R. DOBRE ${ }^{8}$}

\begin{abstract}
Visceral Leishmaniasis (VL) is caused by protozoan of genus Leishmania and transmitted by sand flies of genus Lutzomyia, which has been adapted to the peridomicile environment where dogs are their mainly food source, increasing the risk for human cases. In this study, techniques of geoprocessing and spatial statistics were utilized as a contribution to understanding the epidemiological dynamics of VL in the urban area of Ilha Solteira, SP.
\end{abstract}

KEYWORDS: geoprocessing, sand fly, epidemiology, spatial statistics.

\section{DISTRIBUIÇÃO ESPACIAL DA LEISHMANIOSE VISCERAL CANINA EM ILHA SOLTEIRA, SÃO PAULO, BRASIL.}

RESUMO: A Leishmaniose Visceral (LV) é causada por protozoários do gênero Leishmania e transmitida por flebotomíneos do gênero Lutzomyia, os quais vêm adaptando-se ao ambiente peridomiciliar, onde o cão é sua principal fonte de alimento, aumentando assim o risco de casos em humanos. Neste trabalho, foram utilizadas técnicas de geoprocessamento e de estastística espacial como contribuição à compreensão da dinâmica epidemiológica da LV na área urbana de Ilha Solteira-SP.

PALAVRAS-CHAVE: geoprocessamento, flebotomíneos, epidemiologia, estatística espacial.

\section{INTRODUCTION}

Visceral leishmaniasis (VL) is a zoonosis caused by protozoa of the genus Leishmania (ROSS, 1903) and the species Leishmania infantum (syn. L. chagasi), the main causative agent in regions extending from the southern of United States to the north of Argentina, including Brazil (KUHLS et al., 2011). The transmission occurs through the bite of female sand flies of the Lutzomyia longipalpis (Diptera: Psychodidae: Phlebotominae), and although these vectors feed on different animals, the dog is the main reservoir host of $L$. chagasi in the cycle of transmission to humans in urban areas (SOUZA et al., 2008; PORROZZI et al., 2006; BARATA et al., 2005).

Epidemiological data reveal periurbanization and urbanization of the VL, especially the outbreaks occurred in Rio de Janeiro (RJ), Belo Horizonte (MG), Araçatuba (SP), Santarém (PA), Corumbá (MS), Teresina (PI), Natal (RN), São Luís (MA), Fortaleza (CE), Camaçari (BA) and disease outbreaks in the districts of Tres Lagoas (MS), Campo Grande (MS) and Palmas (TO) (BRAZIL, 2006).

In São Paulo, the first human case of VL was registered in 1999 in the city of Araçatuba, and since then the disease has occurred in cities of the Western Paulista Plateau, where the transmission has only urban feature. The species involved in the transmission, L. longipalpis, was identified in

\footnotetext{
${ }^{1}$ Doutoranda em Ciência Animal, Departamento de Apoio, Produção e Saúde Animal, UNESP, Araçatuba - SP.

${ }^{2}$ Prof. Assistente, Departamento de Fitossanidade e Engenharia Rural de Solos, UNESP, Ilha Solteira - SP.

${ }^{3}$ Prof. Assistente, Departamento de Biologia e Zootecnia, UNESP, Ilha Solteira - SP.

${ }^{4}$ Prof. Assistente, Departamento de Matemática, Estatística e Computação, UNESP, Presidente Prudente - SP.

${ }^{5}$ Prof. Assistente, Departamento de Matemática, Estatística e Computação, UNESP, Presidente Prudente - SP.

${ }^{6}$ Bióloga, Ilha Solteira - SP.

${ }^{7}$ Médico Veterinário, Centro de Controle de Zoonoses, Ilha Solteira - SP.

${ }^{8}$ Médico Veterinário, Centro de Controle de Zoonoses, Ilha Solteira - SP.

Recebido pelo Conselho Editorial em: 22-11-2010

Aprovado pelo Conselho Editorial em: 20-4-2012
} 
the urban area, initially to municipalities contiguous to Araçatuba and then those that established the migratory flow of people and goods in the cities of the region (CAMARGO-NEVES, 2007).

The change in the epidemiological profile of VL from wild / rural to urban environment may be related to socio-environmental issues such as deforestation, unplanned growth of cities, human migration and infected animals, compromising the results of the actions of governmental control programs (MARTINS et al., 2007; BARATA et al., 2005).

Moreover, the inadequacy of traditional methods, insufficient data, which undertakes an analysis of trends over time, makes it necessary to search for new methodologies, which include extensive analysis of time series, the adoption of sentinel events and areas and use of the geoprocessing for the analysis of specific situations of disease production (BARCELLOS et al., 2009).

The use of geoprocessing in conjunction with satellite images are extremely useful tools because they allow greater dynamics in the generation of information, enabling greater productivity, faster update and versatility in handling data (CANDICE et al., 2010). These techniques have also been used in epidemiological studies of endemic diseases transmitted by vectors, or focusing on determining areas at risk of transmission (APARICIO \& BITENCOURT, 2004; MARTINS et al., 2007), the spatial and temporal distribution or incidence of the disease (BELT et al., 2007).

In this context, the objective of this study was to analyze the spatial distribution of the occurrence of the VL in the city of Ilha Solteira by using geoprocessing techniques and spatial statistics as a contribution to the understanding of their epidemiological dynamics and direction of prevention and control.

\section{MATERIAL AND METHODS}

\section{Study area}

The study area comprises the urban area of Ilha Solteira, located in the Western Paulista Plateau, the northwestern region of São Paulo, covering a radius of up to $2 \mathrm{~km}$ of suburban area. The city has an area of $659 \mathrm{~km}^{2}$ and a population estimated at 24,176 inhabitants (IBGE, 2010). The entire urban population is served by the distribution services of drinking water, sewage and garbage. The main economic activity is the generation of electricity through the Ilha Solteira Power Plant and Eco-Tourism (MARQUES \& MANZOLI-JUNIOR 2002).

The municipality reported the first case of Canine Visceral Leishmaniasis (CVL) in 2001 (CAMARGO-NEVES, 2007) and according to the local Center for Zoonosis Control, 469 cases of positive dogs were registered between 2007 and 2008. In relation to human VL, from 2005 to 2008 2 cases were recorded per year.

The remaining natural vegetation consists of tropical evergreen forest, which is also called the humid forest, and semi-deciduous broadleaf forest or dry forest. Most of this original cover was eliminated during the occupation of the area, and it is currently the main cover for the soil represented by anthropic fields (pastures) (SILVA et al., 2006).

The physical characteristics of the soil, according to new nomenclature for the Brazilian System of Soil Classification, is a Dark Red Eutrophic one (SILVA et al., 2005) and the climate of the region, classified according to the International System Köeppen, is tropical humid, with rainy summer and drought in winter, Aw (SILVA et al., 2006). The average monthly temperatures range between $20.5^{\circ} \mathrm{C}$ (July) and $26.2^{\circ} \mathrm{C}$ (February) with the average monthly rainfall ranging from $20 \mathrm{~mm}$ (August) to $254 \mathrm{~mm}$ (January) (CRUZ et al., 2007).

\section{Material}

For the extraction of spatial information about the fragments of natural vegetation surrounding the urban area of Ilha Solteira, Quickbird satellite image was used with a spatial resolution of $0.6 \mathrm{~m}$, blue, green and red bands of the electromagnetic spectrum, dated April $10^{\text {th }}$ 
2006 and an image sensor / satellite, CCD / CBERS point on the orbit and 160/123, passage of July $7^{\text {th }} 2006$ and resolution of $20 \mathrm{~m}$, bands 2 (blue), 3 (green) and 4 (red).

The SPRING software version 4.3.3 (CAMERA, et al, 1996) was used and to perform the field work, a Global Positioning System (GPS) of navigation Garmin brand, model 96S, datum SAD 69 was also used. For the application of spatial statistical technique TERRAVIEW program version 3.3.0 was utilized which was developed by National Institute for Space Research (INPE) (http://www.dpi.inpe.br/ TerraView).

It was used the Geographic Information System (GIS) in the computational treatment of spatial data, acting as a tool to produce maps, support for spatial analysis of phenomena and also as a geographic database, with built-in storage and recovery of spatial information. For the GIS was also possible to apply the techniques of Spatial Statistics and the Estimation Kernel, which enables the verification of clusters of VL cases in certain regions of the studied area.

\section{Method}

To study the possible relationship between VL and the remaining fragments of natural vegetation, eighteen fragments were enclosed found in the vicinity of the urban perimeter of Ilha Solteira, recognized by the aid of a normal color composite of the satellite Quickbird.

Using the Map Distance feature from the SPRING, buffers were created delimiting a radius of $250 \mathrm{~m}$ from the edges of the scanned fragments, due to the flight range of sand flies is between $250 \mathrm{~m}$ and $500 \mathrm{~m}$, reaching up to $1000 \mathrm{~m}$ in exceptional cases, according to CARNEIRO (2007).

Furthermore, through the CCD / CBERS, we have calculated the Vegetation Index (NDVI), where the light gray levels represent areas with higher levels of vegetation and the dark gray ones, the areas of lower vegetation index indicating degraded areas, urbanized areas, exposed soils and water bodies.

To analyze the spatial distribution of Ilha Solteira, its urban area was divided into five sectors and recorded with the aid of the GPS, 322 households, where 469 cases were reported from CVL in 2007/2008 by the local Center for Zoonosis Control.

The VL cases are placed in the context of the analysis of point processes (point events), which interest is in the set of coordinates representing the exact locations of the events. The objective of this analysis is to study the spatial distribution of these points by testing hypotheses about the observed pattern, i.e., if it the grouping is random or if the points have a regular distribution (BAILEY \& GATRELL, 1995).

The Kernel density estimator is a two-dimensional function that considers the events within a region (defined by a radius), counting the points contained therein, indicating the area of higher or lower concentrations of the analyzed events and also aiming at generating a grid in which each cell represents the intensity value, density ratio of attributes, etc.

In the simplest case, in which each point corresponds only to the event, it is an intensity estimator. If $\mathbf{s}$ is an arbitrary location in the region $\mathbf{R}$ and $\mathrm{s}_{1}, \mathrm{~s}_{2}, \mathrm{~s}_{3}, \ldots, \mathrm{s}_{\mathrm{n}}$, are locations of $\mathbf{n}$ observed events, then the intensity at $\mathbf{s}$ estimated as a function of fourth order, whose intensity estimator is expressed as:

$$
\hat{\lambda}_{\tau}(\mathrm{s})=\sum_{\mathrm{h}_{\mathrm{i}} \leq \tau} \frac{3}{\pi \tau^{2}}\left(1-\frac{\mathrm{h}_{\mathrm{i}}^{2}}{\tau^{2}}\right)^{2}
$$

In this study it is possible to adjust a two-dimensional function on the events considered, comprising a surface whose value is proportional to the intensity of samples per unit area. By using this function, it is possible to count all points within a region of influence, considering them by the distance of each location of interest. 


\section{RESULTS AND DISCUSSION}

In the study conducted for the occurrence of VL, in Ilha Solteira, SP, was observed that cases of CVL are dispersed throughout the urban area, however, with the creation of the Kernel density estimator map, a better visualization and record of the cases were possible in the events occurred in the sectors 3 (Jardim Aeroporto) and 4 (Novo Horizonte / COHAB) (Figure 1), where the estimated prevalence was $14.5 \%$ and $12.4 \%$, respectively, which means a range from medium to mediumhigh. The other sectors had prevalence below $10 \%$ ranging from low to medium-low (Table 1, Figure 1).

TABLE 1. Canine VL prevalence rates in the sectors of Ilha Solteira.

\begin{tabular}{c|c|c}
\hline Sectors & Places/Areas & Prevalence rate (\%) \\
\hline 1 & Northwest/Southwest & 7.7 \\
\hline 2 & Santa Catarina & 3.0 \\
\hline 3 & Jardim Aeroporto & 14.5 \\
\hline 4 & Novo Horizonte/COHAB & 12.4 \\
\hline 5 & Northeast & 7.1 \\
\hline
\end{tabular}

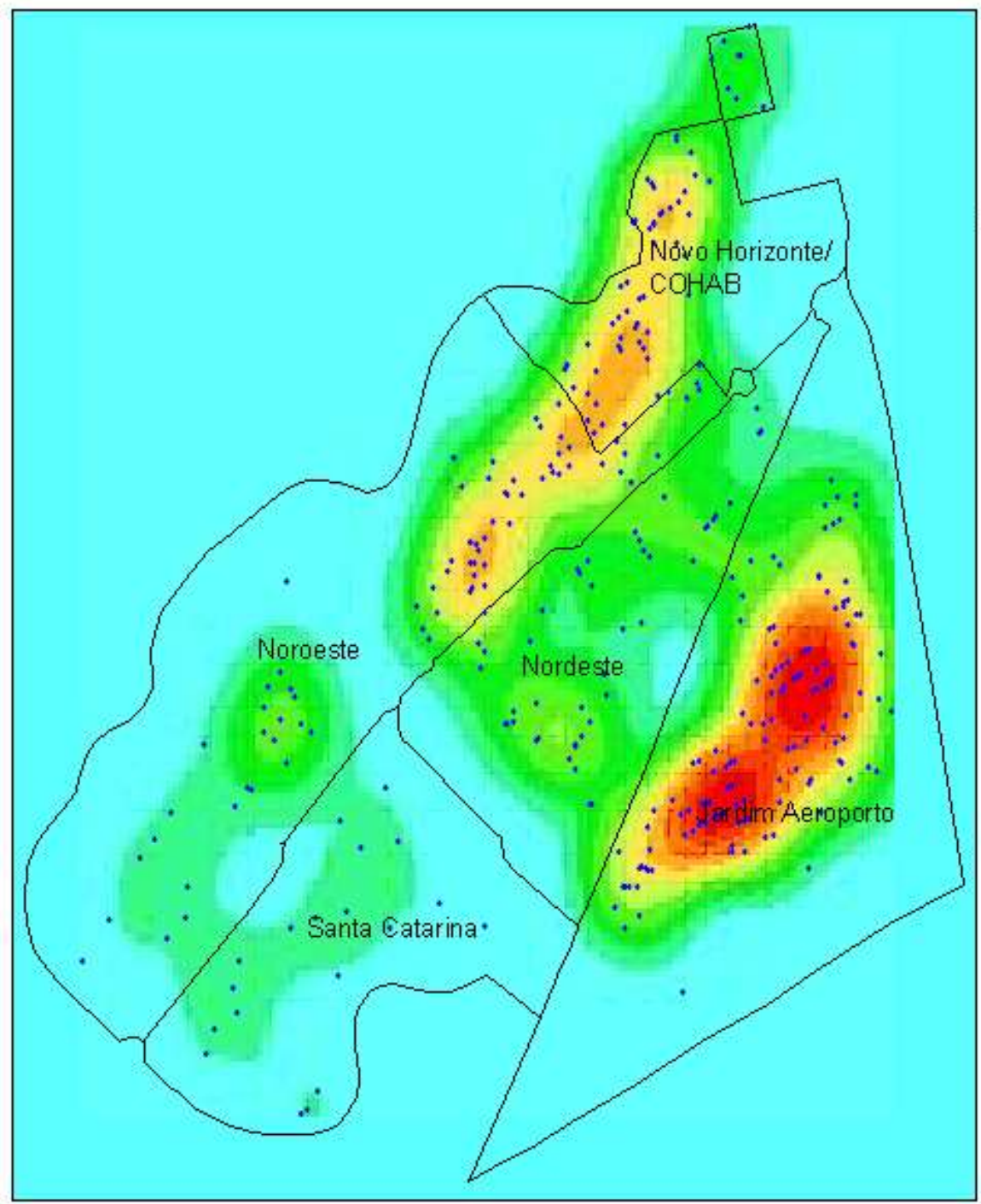

Kernel Density Estimator

\begin{tabular}{|l}
$\square \quad$ Low \\
$\square \quad$ Medium Low \\
$\square \quad$ Average \\
$\square \quad$ Medium High \\
\hline$\square$ \\
Alta \\
\\
$\square \quad$ CVL cases \\
$\square \quad$ Census sector
\end{tabular}

FIGURE 1. Map of Kernel Density Estimator, illustrating the distribution of CVL cases in each sector of Ilha Solteira. 
The areas with higher density for LVC are in certain proximity of fragments of natural vegetation and rural settlement, and are, therefore, far from the city center. Thus, we have defined the fragments of natural vegetation located in the surrounding urban area and $250 \mathrm{~m}$ buffers were created, covering the range of sand flies flights (CANEIRO et al., 2004), from the edges of these fragments.

This analysis revealed that $78 \%$ of cases of CVL were located outside the radius of $250 \mathrm{~m}$, indicating no relationship between the fragments of natural vegetation and the occurrence of CVL in the urban area of Ilha Solteira. MARGONARI et al. (2006) by using GIS techniques to clarify and provide grants for improvements in the plans of action against the VL, also found no relationship between the remnant vegetation and the number of the disease cases.

However, some cases have been recorded within $250 \mathrm{~m}$ of forest fragment relating to the Conservation Center for Ilha Solteira Wildlife (CCFIS) (Figure 2), a place belonging to Zone 4 (Novo Horizonte / COHAB), with the second largest prevalence of CVL. The CCFIS is an area with remnants of natural vegetation preserved and home of wild animals, some of which have already been diagnosed VL positive, such as crab-eating fox (Cerdocyon thous) and bush dogs (Spheotos vinaticus) (ALVES et al, 2009).

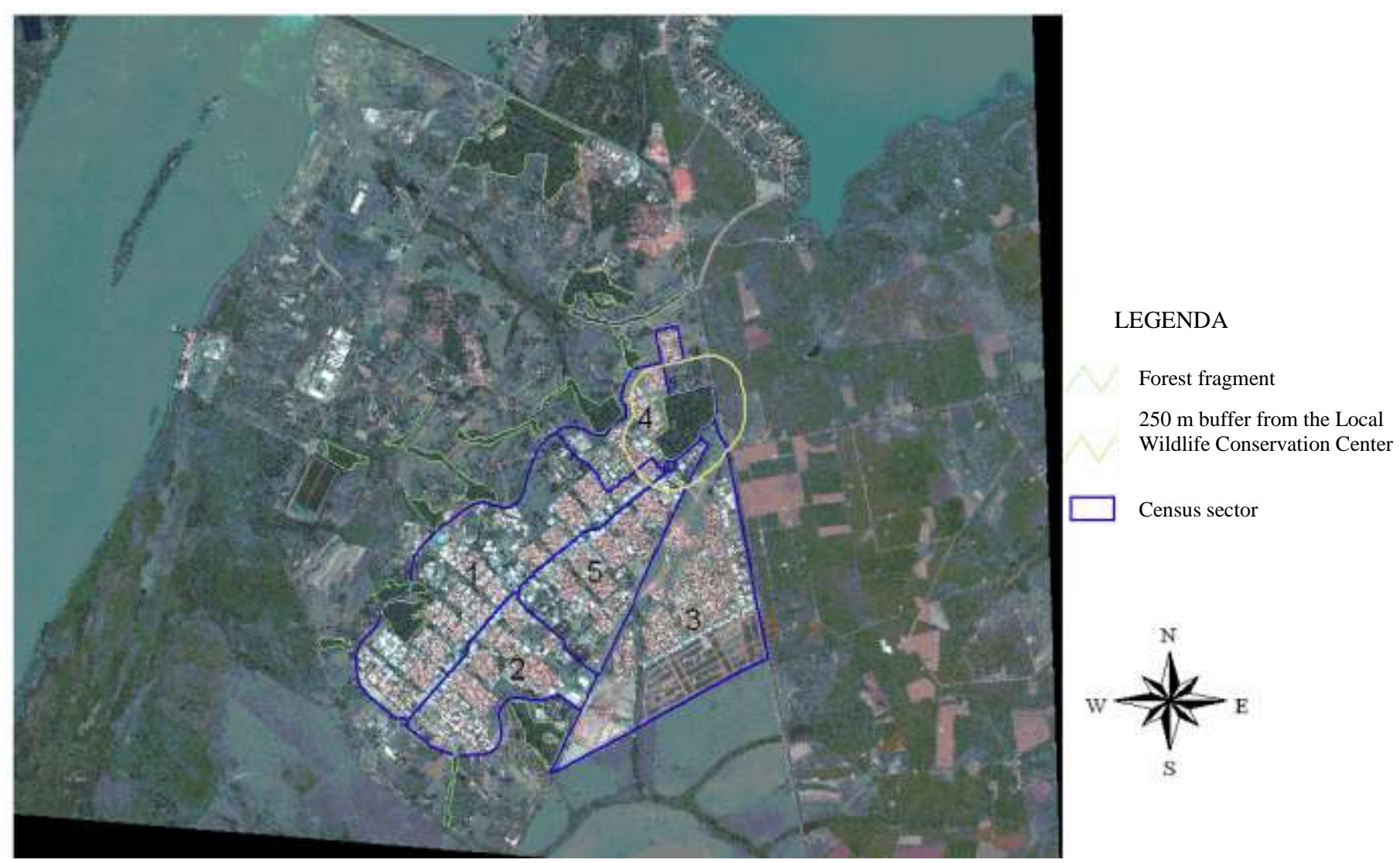

FIGURE 2. Urban area of Ilha Solteira with sectors (1 to 5) delimitation and the forest fragments. Highlighted by the $250 \mathrm{~m}$ buffer, the fragment representing the Local Wildlife Conservation Center.

Figure 3 illustrates the image of the city generated by calculating the Vegetation Index (NDVI), which characterizes the type, quantity and condition of the vegetation presented in a given geographical area (CARNEIRO et al., 2004), in order to observe the conditions of the vegetation in the city and also a possible relation with the positive cases of VL in animals. This analysis shows that the local canopy has a homogeneous and low vegetation index in sectors with greater prevalence for CVL, conversely to that observed in sector 2, a place with greater vegetation cover, 
however, with the lowest number of infected dogs recorded by the municipality CCZ. CARNEIRO et al. (2004) analyzed the relationship between human and canine cases for VL and NDVI, observing human and canine cases and positive presence of sand flies from 500 to $1000 \mathrm{~m}$ from the center point of the higher values of NDVI. MARTINS et al. (2007) have also found no significant association between NDVI and VL cases in a study conducted in Feira de Santana, BA.

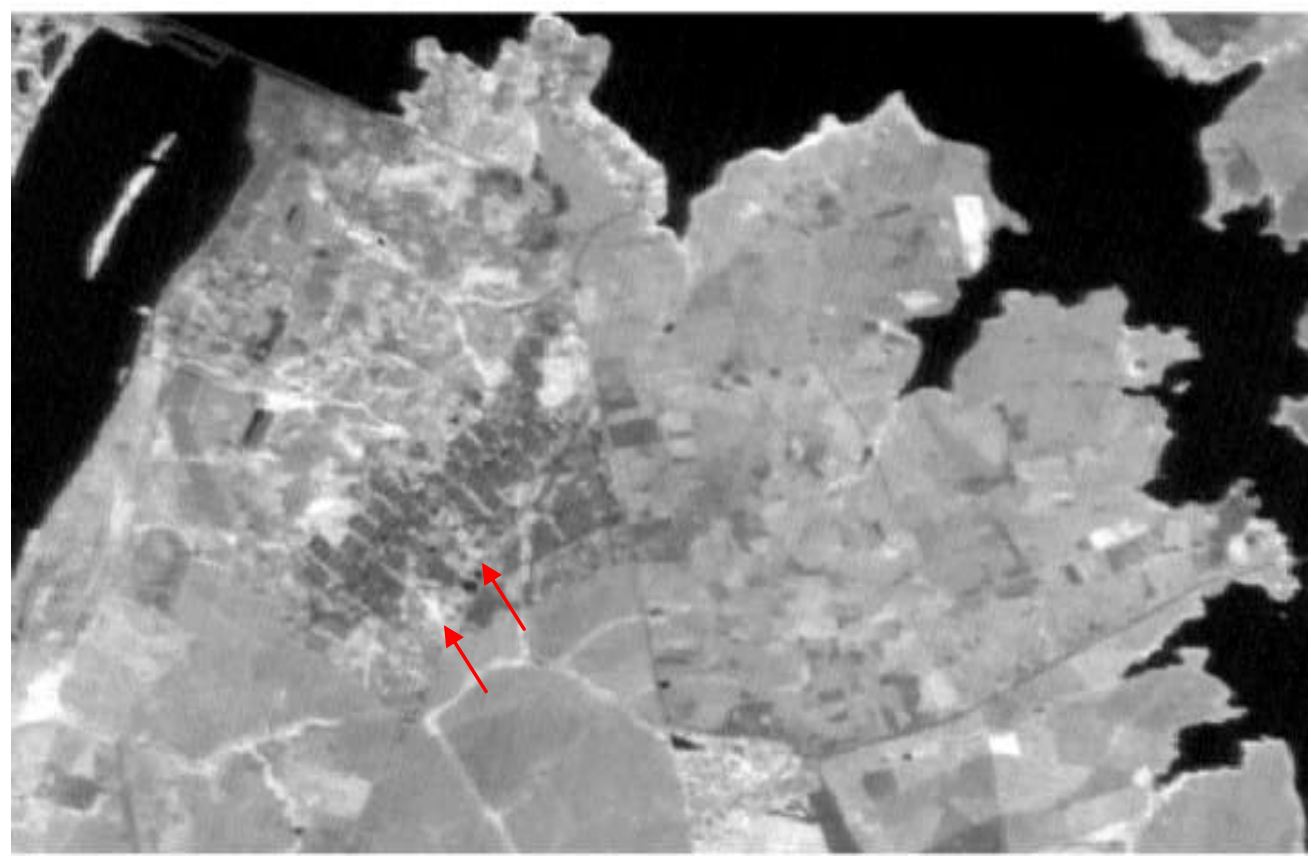

FIGURE 3. NDVI levels of the urban area of Ilha Solteira City, SP. The dark gray parts refer to areas with low vegetation density and light gray ones (arrows) refer to higher vegetation density.

The results have reinforced that the vector adaptation to the peridomicile conditions have relativized the vegetation role as a significant factor in the epidemiological dynamics of the disease, as demonstrated in a study by BARATA et al. (2005), which has found a greater prevalence of the vector $L$. longipalpis both in the household and in the peridomicile environment in relation to other species of sand flies, showing its adaptation to different environments.

In this study, the sectors with highest prevalences of CVL (sector 3 and sector 4) located near the rural settlement called "Estrela da Ilha", implemented in the periurbanized area of Ilha Solteira in February 2005. In this place, dogs with VL positive were found through serological diagnosis conducted in 2008 by the Imunoparasitology Laboratory of Ilha Solteira Engineering College. Many of these animals came from other cities with their respective owners, which makes it possible to presume that they had come from the rural settlement already affected by VL. These data show the importance of migration in the role of VL dispersion, and it could also be observed in the analysis of this disease in the State of São Paulo, performed by CAMARGO-NEVES (2007).

Moreover, high prevalence rates of CVL means greater risk of infections in humans. This relationship between the increased prevalence of CVL and the emergence of human cases is evidenced by several authors in the studies conducted by MARTINS et al. (2007), CARNEIRO et al. (2004), CAMARGO-NEVES et al. (2001), who found a higher incidence of human VL in areas where the number of infected dogs was also higher.

The dispersion of the CVL cases throughout the urban area of Ilha Solteira indicates the peridomicilization of this disease in the city, consequently the dwelling and its surrounding places should be on alert for the implementation of prevention and control and, to a greater effectiveness, it is fundamental to take actions such as health education for the population, vector control, 
identification and elimination of reservoirs and early diagnosis and treatment of human cases, as suggested by OLIVEIRA et al. (2008).

The urban areas where canine prevalence is equal to or greater than $2 \%$, require more intensive action to amend the sanitary conditions that favor the vector proliferation (BRAZIL, 2006). Therefore, a systematic monitoring of the progress of occurrence cases of CVL in Ilha Solteira should be a priority nowadays, considering the potential risk of an outbreak occurrence of human VL in the city.

\section{CONCLUSIONS}

The GIS techniques used in this study allowed the identification of the current pattern of spatial distribution of Ilha Solteira urban area with CVL, demonstrating that the remaining vegetation in the urban environment which is part of the landscape of the city, does not cause problems to the incidence of positive cases in dogs by VL. However, future studies that investigate the determinants in the differentiation of this pattern will direct the implementation of control measures and prevention of visceral leishmaniosis more effectively.

\section{REFERENCES}

ALVES, M.F.; BUZZETI, W.A.S.; PAIXÃO, M.S.; TENÓRIO, M.S.; QUINTAL, A.P.N. Levantamento de Leishmaniose Visceral em marsupiais Didelphis albiventris capturados no centro de conservação da fauna silvestre no município de Ilha Solteira, São Paulo, Brasil. Disponível em: <http://prope.unesp.br/xxi_cic/27_34312211817.pdf>. Acesso em: 3 jul. 2010.

APARICIO, C.; BITENCOURT, M.D. Modelagem espacial de zonas de risco da leishmaniose tegumentar americana. Revista de Saúde Pública, São Paulo, v.4, n.38, p.511-516, 2004.

BAILEY, T.C.; GATRELL, A.C. Interactive spatial data analysis. Essex: Longman Scientific and Technical, 1995.

BARATA, R.A.; FRANÇA-SILVA, J.C.; MAYRINK, W.; SILVA, J.C.; PRATA, A.; LOROSA, E.S.; FIÚZA, J.A.; GONÇALVES, C.M.; PAULA, K.; DIAS, E.S. Aspectos da ecologia e do comportamento de flebotomíneos em área endêmica de leishmaniose visceral, Minas Gerais. Revista da Sociedade Brasileira de Medicina Tropical, Uberaba, v.38, n.5, p.421-425, 2005.

BARCELlOS, C.; MONTEIRO, A.M.V.; CORVALÁN, C.; GURGEL, H.C.; CARVALHO, M.S.; ARTAXO, P.; HACON, S.; RAGONI, V. Mudanças climáticas e ambientais e as doenças infecciosas: cenários e incertezas para o Brasil. Epidemiologia e Serviços de Saúde, Brasília, v.18, n.3, p.285-304, 2009.

BRASIL. Ministério da Saúde. Manual de vigilância e controle da Leishmaniose Visceral. Brasília: Editora do Ministério da Saúde, 2006. 120 p.

CÂMARA, G.; SOUZA, R.C.M.; FREITAS, U.M.; GARRIDO, J. SPRING: integrating remote sensing and GIS by object-oriented data modelling. Comput Graph, v.20, p.395-403, 1996.

CAMARGO-NEVES, V.L.F. A Leishmaniose Visceral Americana no Estado de São Paulo: situação atual. Boletim Epidemiológico Paulista, São Paulo, v.4, p.12-14, 2007. Disponível em: <http://www.cve.saude.sp.gov.br/agencia/bepa6_lva.htm>. Acesso em: $1^{\underline{0}}$ maio 2010.

CAMARGO-NEVES, V.L.F.; KATZ, G.; RODAS, L.A.C.; POLETTO, D.W.; LAGE, L.C.; SPÍNOLA, R.M.F.; CRUZ, O. G. Utilização de ferramentas de análise espacial na vigilância epidemiológica de leishmaniose visceral americana - Araçatuba, São Paulo, Brasil, 1998-1999. Caderno de Saúde Pública, Rio de Janeiro, v.17, n.5, p.1263-1267, 2001.

CANDIDO, H.G.; GALBIATTI, J.A.; PISSARRA, T.C.T.; MARTINS FILHO, M.V. Degradação ambiental da bacia hidrográfica do rio Uberaba: uma abordagem metodológica. Engenharia Agrícola, Jaboticabal, v.30, n.1, 2010. Disponível em: 
<http://www.scielo.br/scielo.php?script=sci_arttext\&pid=S0100-

69162010000100019\&lng=en\&nrm=iso>. Acesso em: 29 out. 2010. Doi: 10.1590/S010069162010000100019.

CARNEIRO, D.D.M.T. Geoprocessamento e análise espacial de varredura no estado-da-arte da Leishmaniose Visceral Americana na região centro-oeste da Bahia, Brasil. 2007. 185 f. Dissertação (Mestrado) - Universidade Federal da Bahia, Salvador, 2007.

CARNEIRO, D.; BAVIA, M.E.; ROCHA, W.; LOBÃO, J.; FILHO, C.M.; OLIVEIRA, J.B.; SILVA, C.E.; BARBOSA, M.G.; RIOS, R. Identificação de áreas de risco para a leishmaniose visceral americana, através de estudos epidemiológicos e sensoriamento remoto orbital, em Feira de Santana, Bahia, Brasil (2000-2002). Revista Baiana de Saúde Pública, Salvador, v.28, n.1, p.19-32, 2004.

CORREIA, V.R.M.; MONTEIRO, A.M.V.; CARVALHO, M.S.; WERNECK, G.L. Uma aplicação do sensoriamento remoto para a investigação de endemias urbanas. Caderno de Saúde Pública, Rio de Janeiro, v.5, n.23, p.1015-1028, 2007.

CRUZ, D.S.; CARVALHO, S.L.; LIMA, E.C.F.; COSTA, S.M.A.L.; BUOZO, J.C.; SILVA, H.R.; ALTIMARE, A.L. Avaliação das condições ambientais das margens da área do braço denominado "da anta" do rio Paraná na área de entorno do reservatório de Ilha Solteira-SP. In: CONGRESSO DE ECOLOGIA DO BRASIL, 8., 2007, Caxambu. Anais... p.1-2.

KUHLS, K.; ALAM, M.Z.; CUPOLILLO, E.; FERREIRA, G.E.M.; MAURICIO, I.L.; ODDON, E.R.; FELICIANGELI, M.D.; WIRTH, T.; MILES, M.A.; SCHONIAN, G. Comparative microsatellite of new world Leishmania infantum reveals low heterogeneity among populations and recent old world origin. PLoS Neglected Tropical Diseases, v.5, n.6, e.1155, 2011.

IBGE. INSTITUTO BRASILEIRO DE GEOGRAFIA E ESTATÍSTICA. Censo demográfico 2007: dados básicos.

IBGE. INSTITUTO BRASILEIRO DE GEOGRAFIA E ESTATÍSTICA. Disponível em: http://www.ibge.gov.br/cidadesat/painel/painel.php?codmun=352044>. Acesso em: 3 maio 2010.

MARGONARI, C.; FREITAS, C.R.; RIBEIRO, R.C.; MOURA, A.C.M.; TIMBÓ, M.; GRIPP, A.H.; PESSANHA, J.E.; DIAS, E.S. Epidemiology of visceral leismaniasis through spatial analisis in Belo Horizonte municipality, state of Minas Gerais, Brazil. Memórias do Instituto Oswaldo Cruz, Rio de Janeiro, v.101, n.1, p.31-38, 2006.

MARQUES, A.P.; MANZOLI-JUNIOR, W. Rede Geodésica do Município de Ilha Solteira RGMIS. In: CONGRESSO BRASILEIRO DE CADASTRO TÉCNICO MULTIFINALITÁRIO, 5., 2002, Florianópolis. Anais... Florianópolis: UFSC, 2002. Disponível em: http://geodesia.ufsc.br/Geodesia-online/arquivo/cobrac_2002/015/015.htm. Acesso em: 09 nov. 2007.

MARTINS, M.S.; BAVIA, M.E.; SILVA, A.B.; CRDIM, L.L.; CARNEIRO, D.D.M.T. Técnicas de Geoprocessamento aplicadas no estudo de risco ambiental da Leishmaniose Visceral em área urbana de Feira de Santana, Bahia. In: SIMPÓSIO BRASILEIRO DE SENSORIAMENTO REMOTO, 13., 2007, Florianópolis. Anais... Florianópolis: INPE, 2007. p.2825-2832.

OLIVEIRA, C.D.L.; MORAIS, M.H.F.; MACHADO-COELHO, G.L.L. Visceral leishmaniasis in large Brazilian cities: challenges for control. Caderno de Saúde Pública, Rio de Janeiro, v.24, n.12, p.2953-2958, 2008.

PORROZZI, R.; PEREIRA, M.S.; TEVA, A.; VOLPINI, A.C.; PINTO, M.A.; MARCHEVSKY, R.S.; BARBOSA Jr., A.A.; GRIMALDI Jr., G. Leishmania infantum induced primary and challenge infections in rhesus monkeys (Macaca mulatta): a primate model for visceral leishmaniasis. Transactions of the Royal Society of Tropical Medicine and Hygiene, London, v.100, n.10, p. 926-937, 2006. 
ROSS R. Further notes on Leishman's bodies. British Medical Journal, London, v.2, n.2239, 1903.

SILVA, H.R.; ALTIMARE, A.L.; LIMA, E.A.C.F. Sensoriamento remoto na identificação do uso e ocupação da terra na área do projeto "Conquista da Água", Ilha Solteira - SP, Brasil. Engenharia Agrícola, Jaboticabal, v. 26, n. 1, 2006 . Disponível em:

$<$ http://www.scielo.br/scielo.php?script=sci_arttext\&pid=S0100-

69162006000100035\&lng=en\&nrm=iso>. Acesso em: 29 oct. 2010. Doi: 10.1590/S010069162006000100035.

SILVA, E.S.; GONTIJO, C.M.F.; MELO, N.M. Contribution of molecular technique to the epidemiology of neotropical Leishmania species. Trends in Parasitoogy, Oxford, v.21, p.550-552, 2005.

SOUZA, V.M.M.; JULIÃO, F.S.; NEVES, R.C.S.; MAGALHÃES, P.B.; BISINOTTO, T.V.; LIMA, A.S.; OLIVEIRA, S.S.; MOREIRA Jr., E.D. Ensaio comunitário para avaliação da efetividade de estratégias de prevenção e controle da leishmaniose visceral humana no Município de Feira de Santana, Estado da Bahia, Brasil. Epidemiologia e Serviços de Saúde, Brasília, v.17, n.2, p.97-106, 2008. 